Archaeological Journal

\title{
Yorkshire Plate and Goldsmiths
}

\section{T. M. Fallow M.A., F.S.A.}

To cite this article: T. M. Fallow M.A., F.S.A. (1904) Yorkshire Plate and Goldsmiths, Archaeological Journal, 61:1, 74-83, DOI: 10.1080/00665983.1904.10852962

To link to this article: http://dx.doi.org/10.1080/00665983.1904.10852962

$$
\text { 曲 Published online: } 17 \text { Jul } 2014 .
$$

Submit your article to this journal 준

LII Article views: 2

Q View related articles $\asymp$ 


\section{YORKSHIRE PLATE AND GOLDSMITHS. ${ }^{1}$}

By T. M. FALLOW, M.A., F.S.A.

I propose in the following paper to state very briefly what old plate we have in public hands in Yorkshire, without entering much into detail, and then to say a few words about Yorkshire goldsmiths and their work, and the marking of their plate.

In the first place-as to the old plate which the county possesses.

There are two good collections of old plate, one belonging to the Corporation of this city, and the other to the Trinity House of Kingston-on-Hull.

There are also some interesting pieces of municipal plate at Hedon and Richmond, but as all the Corporation Plate has been fully described by my friend Mr. W. H. St. John Hope in the second volume of Corporation Plate and Insignia of Office, and as I have myself dealt pretty fully with the plate at Trinity House, Kingston-onHull, in the first and second volumes of the New Series of the Reliquary, I shall pass these by, merely drawing attention to the gold loving cup belonging to the city of York, as it is unique in being the only piece of old English gold plate made by a local goldsmith and bearing provincial hall-marks. It was made by the well known York goldsmith, Marmaduke Best, whose mark it bears together with those of the old York goldsmith's hall for 1672 .

Passing to ecclesiastical plate it is again impossible to attempt a description of individual pieces, although a few may be mentioned in a general sort of way,

We have three pre-Reformation chalices, viz., Hinderwell (with its paten), Beswick (much damaged, with its paten), and Goathland (without a paten). They have been fully described by Mr. Hope and myself in

1 Read at the York Meeting of the Institute, 21st July, 1903. 


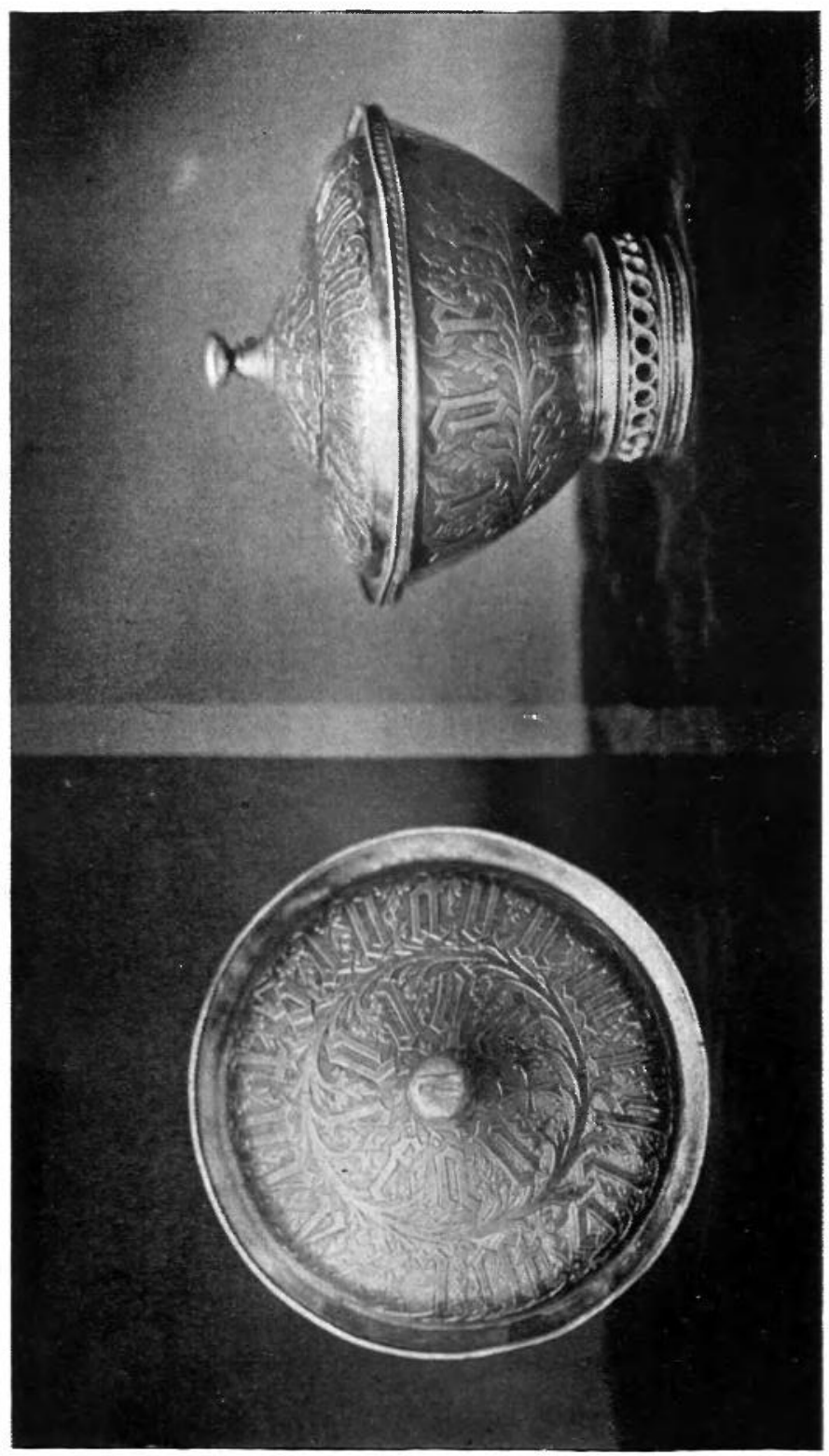

觜 


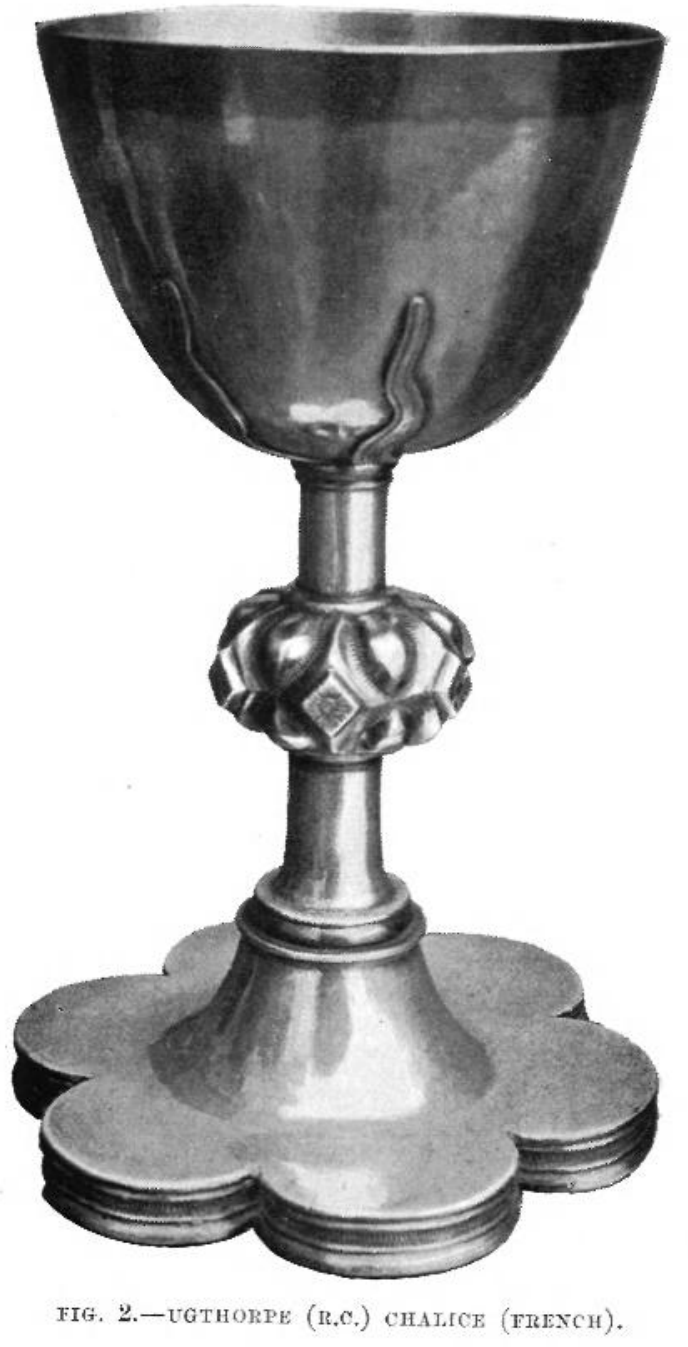


volume 43 of the Archaeological . Iournal and also by Mr. Cripps in Old English Plate.

None of these vessels bear hall-marks, and it seems quite possible that some, at least, are of local manufacture. I am inclined to think from the peculiarities of the Hinderwell paten, and those of the Goathland chalice, that both may be of local Yorkshire make.

The Hinderwell paten is unlike any other that has been found. It is a very thin and perfectly plain saucer, with a simple concave depression and a plain wide rim. In its centre is very lightly engraved a representation of the Holy Lamb. As it exactly fits the chalice the inference is that if its peculiarities point to local work, the chalice (although itself normal in design) is also of local make.

The thick-set build of the Goathland chalice, and its rude knot in the centre of the stem, all very unlike anything elsewhere, suggest that it also may be a piece of local work.

There is also a pre-Reformation paten with the London marks of 1517, and having in its centre the Vernicle, or Face of Our Lord. This paten was bought by the late Rev. T. Staniforth in, I believe, the South of Fngland. $\mathrm{He}$ bequeathed it to his nephew Major Stanyforth, who has given it to Kirk Hammerton Church.

Mention ought also to be made of the three early chalices with their patens at the Minster. They were found about 150 years ago in the graves of some of the Archbishops. The late Dean, Dr. Duncombe, had them repaired, and they are now occasionally used at the Minster services. In mentioning mediaeval plate the Scrope mazer bowl ought not to be forgotten, but all these vessels have been so often described and figured that a further account of them here is not needed.

By far the most curious, and perhaps most beautiful piece of mediaeval plate which we possess, is the vessel now in use at Aldfield (otherwise Studley) Church near Ripon as an alms basin (fig. 1). I am only sorry that we cannot claim it as of Yorkshire make.

It will be seen from the illustrations that both on the bowl, and again on the cover, there is a sort of tree 
of knowledge which encircles each piece, and which bears alternately in two rows leaves and the letters of the alphabet in small black-letter characters. On the knop of the cover the letter a occurs. It is, however, repeated in its proper place at the beginning of the alphabet. Both on bowl and cover there follows after the letter $\dot{i}$, what would seem to be a sentence formed of the contractions for $\mathfrak{e t}, \mathfrak{u r}$, and $\mathfrak{c o u}$ coupled by the word $\mathfrak{e s t}$ in full-thus : $\mathfrak{e t} \mathfrak{e s t} \mathfrak{u r}$ com.

I consulted the late Sir Wollaston Franks about this piece. He stated that he had never seen anything like it, that he thought it was early fifteenth century work, not English (owing to the absence of the letter $\mathfrak{w}$ ) but probably French.

He further wrote, "The letters at the end of the alphabet are exceedingly puzzling. I have shown them in the Manuscript Department, and we can only conjecture that they are the contractions generally in use, but this does not explain est. ${ }^{1}$ You are lucky to have found the reference to Testamenta Eboracensia, which is very appropriate."

This reference is to the will of John Morton, esquire, of York, who, in 1431, bequeathed to Robert Gaytenby, his cousin, inter alia, a very similar vessel described as "unum collok pece argenti cum scriptura A.B.C...in cooperculo" _ a collok piece of silver with the A.B.C. in the cover. I have mentioned this vessel at length because $I$ think it is perhaps the most remarkable piece of plate that we have. It stands $5 \frac{1}{9}$ inches in height with its cover on, and the diameter of the bowl is the same.

Before leaving the subject of mediaeval plate allusion should be made to a couple of chalices at the private Roman Catholic Chapel attached to Danby Hall, the seat of Mr. Scrope. They follow the outlines of pre-Reformation chalices so closely, that it is only an examination of the detail of ornamentation which reveals the fact that they are of rather later date. I have a

1 It was suggested by the Rev. $A$. Du Boulay Hill, at the meeting, that the contractions are of a character with the " ampersand," and are not intended to form a sentence. This seems after all the most probable explanation, though it does not explain the presence of the word esit.

2 Test. Ebor., II. p. 15. 
To face page 76.

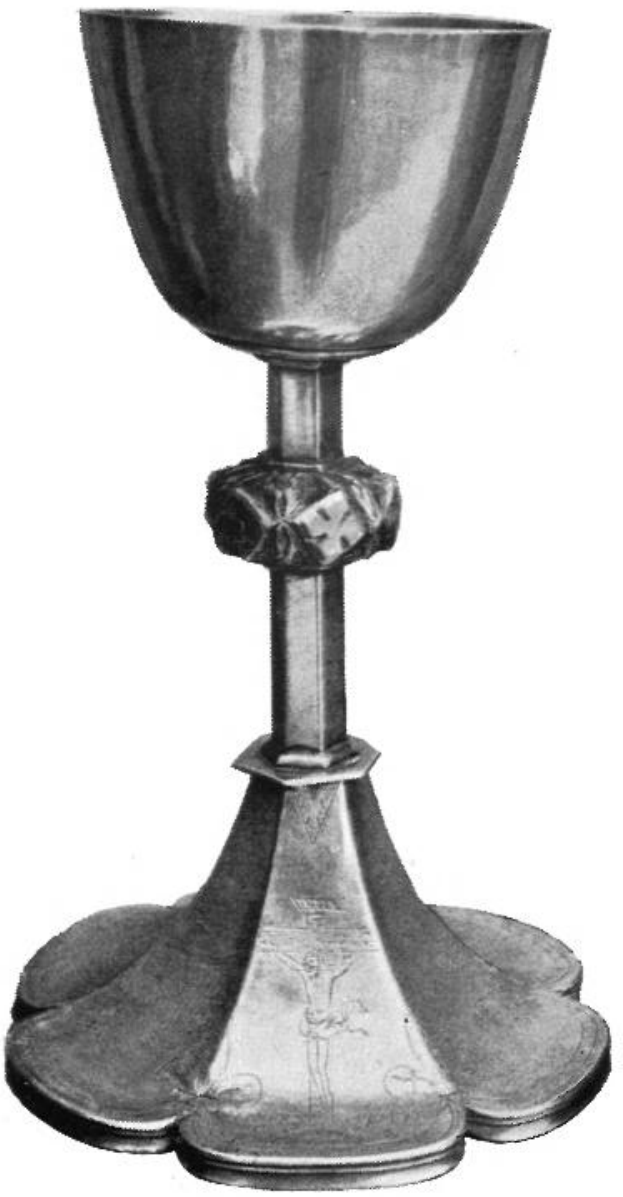

fia. 3.- -ugthorpe (R.c.) chatice (engltsh c. 1630). 

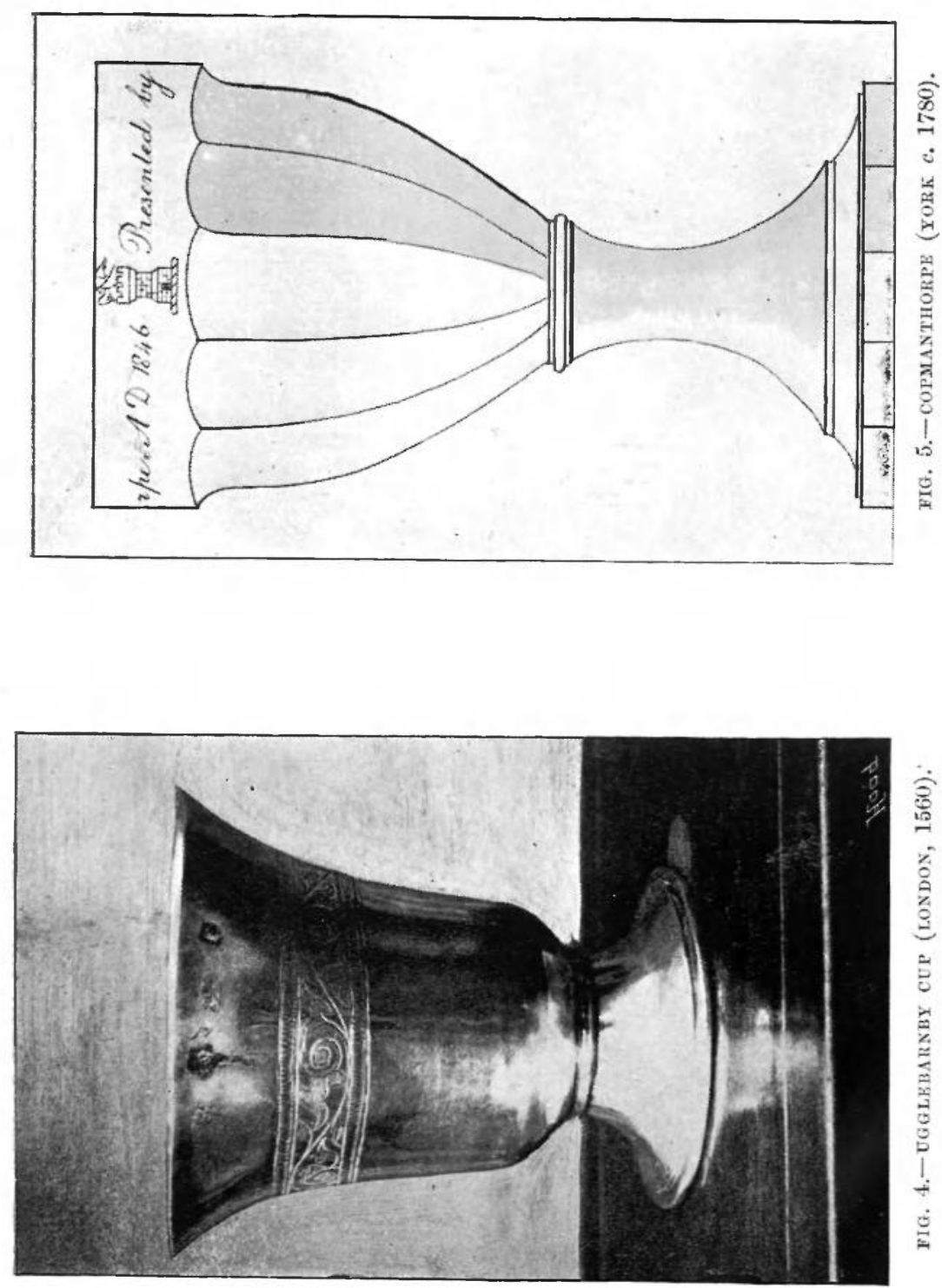
theory that they may have been made during the temporary revival of Roman Catholicism under Queen Mary.

At Ugthorpe, near Whitby, there are two other interesting Roman Catholic chalices. One of them is a French chalice (fig. 2) with wavy flames round the bowl. It unscrews into three pieces for the purpose of being carried about. The other one (fig. 3) is probably English as it corresponds with similar chalices having English marks elsewhere. Both these chalices are interesting as having been those ordinarily used by the well known Nicholas Postgate, who, at the age of eightytwo, was barbarously hanged at York in 1679 for saying Mass.

Mr. Postgate had for many years gone about in danger of his life, ministering to the unhappy recusants who had taken refuge in the wild moorland districts near Whitby. He was, at length, betrayed by a wretched exciseman for $£ 20$, was taken to York, tried, and executed. There are still thriving colonies of Roman Catholics in the districts Mr. Postgate served, and some linen sheets are preserved at Ugthorpe which used to be spread (as if to air) on the hedges, as a signal that he was in a neighbouring house, and about to say Mass.

As regards the subject of post-Reformation church plate generally, I have made a rough (but not I think inaccurate) estimate that we have about 3,000 pieces of a date anterior to 1800 in Yorkshire. It is obviously impossible to attempt individual descriptions of those pieces. Among them we have the usual proportion of handsome secular vessels devoted by their owners, at different times, for the ministrations of the sanctuary.

A few pieces are illustrated for the purpose of pointing out special peculiarities or local work, rather than for a particular description of the vessels themselves.

The little cup at Ugglebarnby near Whitby (fig. 4) is a curious little vessel in itself. It is probably the smallest Elizabethan Communion Cup in existence, as it is only $3 \frac{1}{8}$ inches in height. It is of more interest, perhaps, on account of its hall-marks. These are those of the London hall for 1560, and the date letter (a small c) is placed in a shield. This really marks an important 
national event-the restoration by Queen Elizabeth of the old sterling standard of the country's silver. This took place in the middle of the Assay year, and an Ordinunce of the London Goldsmiths' Company, dated 16 th December, 1560, directs that the date letter $\mathfrak{l}$ for the rest of the year shall "be grayved round about for a difference." It is so "grayved round about" on the Ugglebarnby Cup, and on no other piece of plate that is known.

Of our old church plate, by far the larger amount bears London marks, but a considerable quantity, between 1570 and 1700, has old York marks. About forty pieces (mostly in the East Riding) from 1580 to 1700 have Kingston-on-Hull marks, and a few have odd marks attributable to Leeds and other places. During the eighteenth century much fine massive plate came from Newcastle, and a smaller proportion of vessels of that date bears modern York marks. One (fig. 5) specimen of the latter (a cup made and marked about 1780) was given in 1846 to Copmanthorpe near York, and is included among the illustrations. We have only two pieces of old Scottish plate and none I think from Ireland.

I now pass to the second part of my paper, that dealing with the goldsmiths of Yorkshire and their work, and the local marking of plate.

The city of York was from an early period a centre of goldsmithery, and much concerning the old York goldsmiths has been given in Old English Plate by Mr. Cripps, and need not be repeated now. In 1277 we find an "orbatur" entered as a freeman, and in 1303 a full-fledged "aurifaber" appears. He was the first of a long and honourable line of craftsmen, whose work was for the first time checked in 1697 by the mistaken legislation which abolished the provincial Goldsmiths' Companies. York never recovered from that blow, although specially named in the repealing Act of 1701 . Its work afterwards was fitful and irregular, and although plate continued to be marked till 1856, there was little real work done.

Of old, the York Goldsmiths' Company was an important city "mystery" or guild, annually taking its 

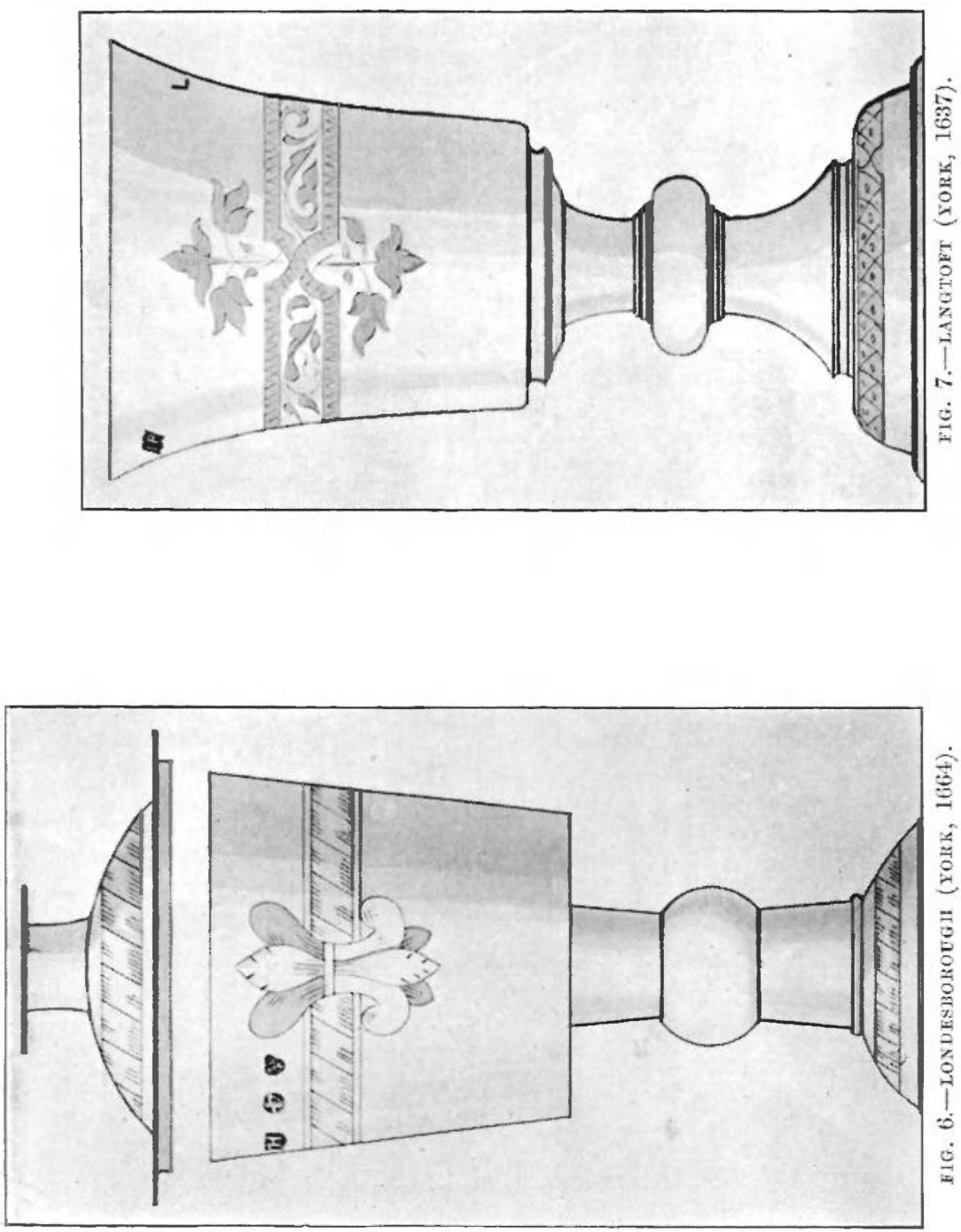


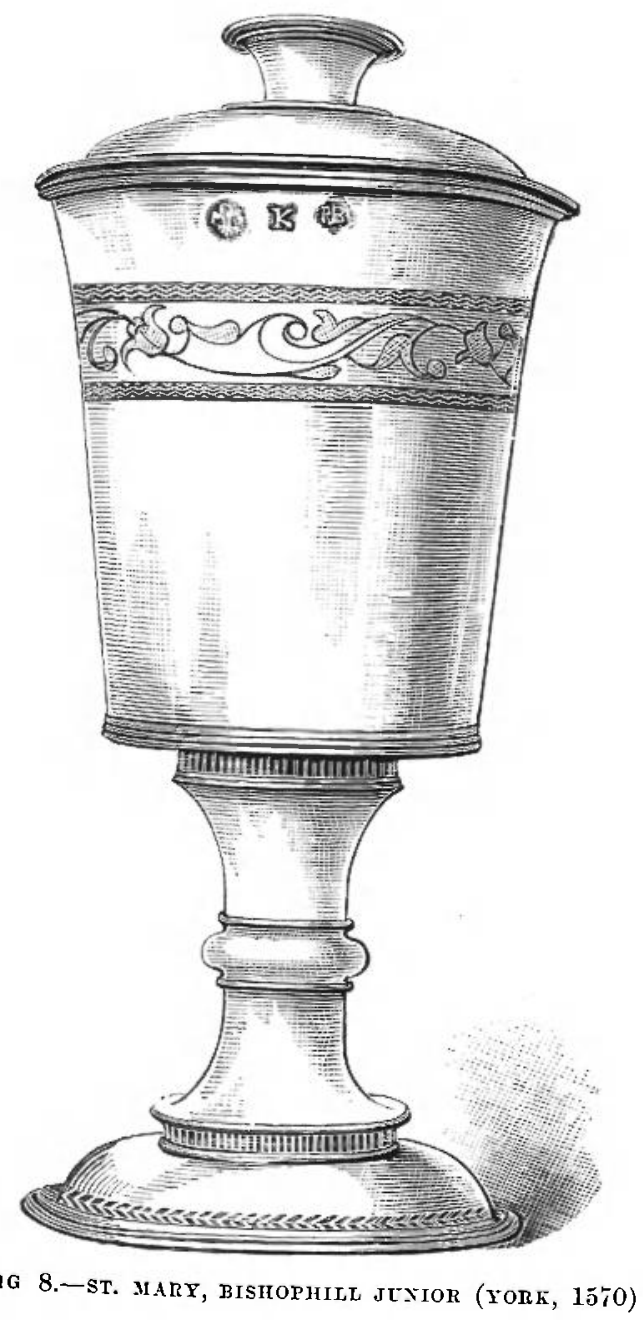

Block lent by the Forkshive Archacological Sociely. 
part in the civic pageants on Corpus Christi Day, and having its own celebration on the feast of St. Dunstan. York, it may be remembered, was one of the seven provincial towns in which a recognised "touch" for gold and silver plate was to be set up by Parliament in 1428, the others being Canterbury, Salisbury, Lincoln, Coventry, Bristol, and Newcastle-upon-Tyre. More will be said as to the Act of 1428 when speaking of Kingston-on-Hull, but it is well to call attention to the fact that prior to 1428 York had its mark for plate fully recognised, and apparently well known. This seems evident from the way in which "le comune touch de la cite" is spoken of in 1412 . It was no doubt then, what we know that it was later, when it is referred to in the Elizabethan Ordinances of the York goldsmiths as "the half leopard's head and half fleur de lys."

Indeed, I think we have an example of it struck in the bowl of a spoon dredged from the bed of the river Hull some years ago, and now the property of Dr. Stephenson of Beverley. This mark is the only instance of a mediaeval York hall-mark known. Taking it as the earliest form known of the City punch used at York, four other distinct punches are found on York plate.

The second punch is only found in 1570 and 1571. It occurs on about thirty Elizabethan Communion Cups, but how long it was used we cannot tell, as there are no other pieces of plate to show till we come to the third punch which is first found with the letter Z of 1583. and definitely ends in 1624 .

The fourth punch begins with the $S$ of 1625 , and definitely ends with the $W$ of 1697 .

The fifth and last punch begins in 1680 and continues to the close of the old York office in 1697. After the revival of the York office in 1700 the City arms (a shield of five lions on a cross) became the City mark according to the terms of the Act of Parliament. Very often, however, this cumbersome stamp was omitted, and the marks are exactly like ordinary London marks except that the date-letter differs. When, in 1877, Mr. Cripps and I first came upon one of these defective modern York marks we were thoroughly puzzled, and it was only afterwards finding exactly the same group of marks 
combined with the York City punch, that the riddle was solved.

In $15 \mathrm{~s} 3$ complaints were made as to the work of some of the York goldsmiths by the searchers of the Company. One of the goldsmiths implicated, George Kitching by name (whose mark occurs on cups at Bolton Percy and Rufforth churches). repudiated the charge, and he and one of the York searchers were sent to the "Saye Master" of the London goldsmith's hall to have the inculpated plate tested again. The result seems to have been favourable to Kitching. The "Saye Master" passed the plate as good, and in the award that followed, the York searchers had to pay Kitching the value of his pieces of plate which they had broken, and they were also ordered to refund him the cost of his journey to London and back. Probably they left Mr. Kitching alone after this. The incident is of importance as showing the care the York Goldsmiths' Company took that their work should be severely tested, and not allowed to be evil spoken of.

The York goldsmiths have no splendid monument of their work to show, like the cup which Peter Peterson left behind him at Norwich, but there are plenty of honest and comely vessels up and down the county to testify to their skill and good workmanship. Several of these are to be seen in the Corporation Plate of this city, and in many Yorkshire churches. At Ripon Minster there is a handsome and complete set of plate, with curious standing covers or " aires," as they are called (both the name and idea are borrowed from the Greek ritual) to the patens. This set of plate was made by John Plummer of York, in 1676, whose receipt for it is still preserved.

The pictures of the cups will give an idea of the characteristics of York-made Communion Cups. Two peculiarities ought to be mentioned, one is that the band of ornament round the bowl is retained till quite late. It is, of course, a survival of the Elizabethan belt of strap-work with leaves in it, so commonly found in all parts of the country on Elizabethan cups. At York it continued to the last. There is, I think, an instance after 1690. At times it is of a stiff character as on (fig.6) 

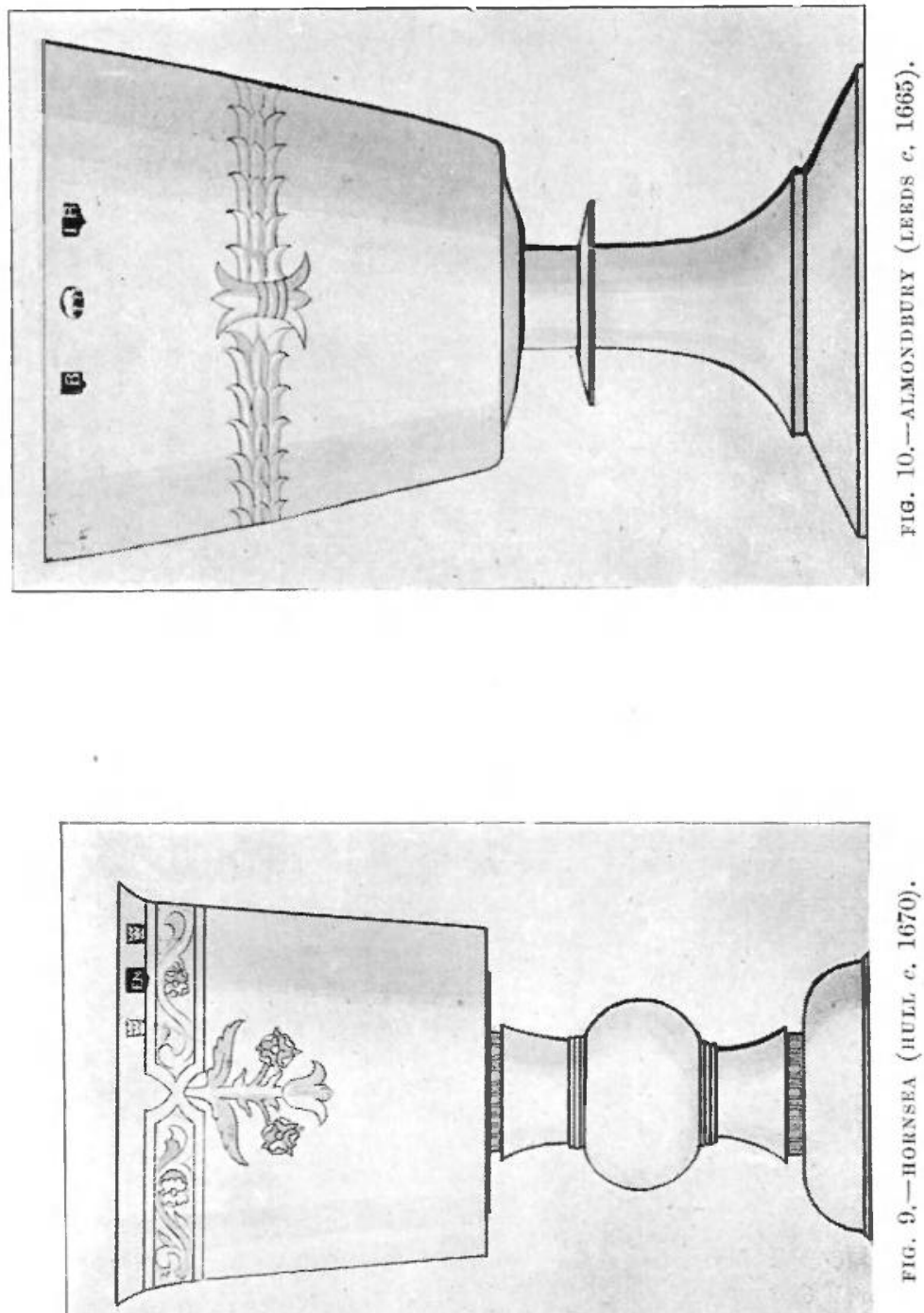


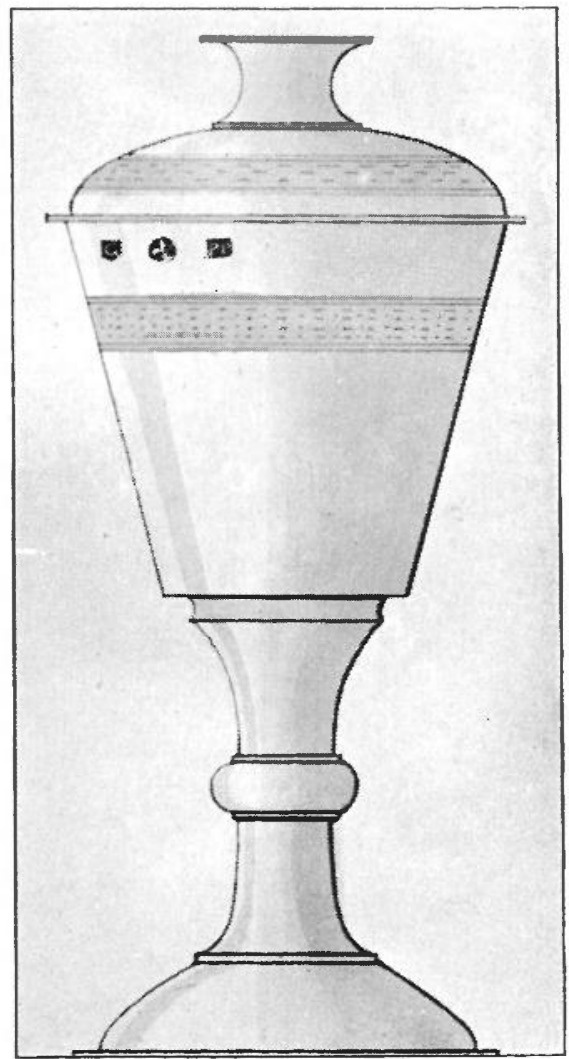

FIG. 11--SLTTON-ON-DERWENT (YORK, 161U). 
the Londesborough cup of 1664, but it is more often like that on (fig. 7) Langtoft cup of 1637 , and this latter form is continued till quite late. The other peculiarity is the square shape of the bowls of many of the cups. This is well seen in the pictures of the cups at St. Mary, Bishophill Junior York (fig. 8), and Hornsea (fig. 9) respectively.

With regard to Kingston-on-Hull there is practically no documentary information available. All we know is that from 1587 to 1700 there was a continuous making and marking of plate in that town. Kingston on-Hull was not named in the Act of 1428. Neither were Exeter or Chester, at both of which towns much plate was also made and marked, while at four of the towns named in the Act of 1428, viz. Canterbury, Salisbury, Bristol, and Coventry, no trace can be found of that Act having taken effect. We have evidence of this in the fact that a mediaeval vessel at Sandwich near Canterbury is marked with the arms of Sandwich, and not with those of Canterbury, as would have been the case had the 1428 Act been in force at Canterbury. There is again, no trace of a mark at Salisbury, but plate was markcd at Dorchester and Sherborne. Again while an old Bristol ${ }^{1}$ mark has yet to be found, the mark of the neighbouring town of Taunton, though rare, is well known. It is evident that.the 1428 Act had little effect in practice, and it will be remembered that it did not even originate the York mark. Too much has been made of it, and we must look to the common right and duty of every mayor or head officer of a borough to control the work of the craftsmen, of whatever sort, in that town, as the origin of and authority for the Kingston-on-Hull mark and for those of Chester, Exeter, and other towns.

The Kingston-on-Hull goldsmiths (specimens of whose work have been found) are eight in number, and it would almost seem that each of them struck his own rersion of the town punch, for that punch varies in each case.

1 At the discussion which followed Mr. St.'John Hope stated that he had seen a spoon with what was undoubtedly an old Bristol mark, but this is the only instance noted. A single instance of modern Bristol hallmarks occurs on a spoon at the Temple Church there.
These marks are (1) the maker s initials R.G.; (2) a capital Roman A in a pointed shield; (3) lion passant; (4) leopard's head crowned; (5) an oblong punch with the arms of the city of Bristol. 
There are about fifty pieces of Hull plate in public hands. At first the mark used was the letter $\mathrm{H}$. Then the letter $\mathrm{H}$ and a shield of the three ducal crowns (the arms of the town) were combined; and then the arms were used alone, or for a short time with a date-letter.

There is a fine deep Elizabethan cup at Trinity Church, Hull, dated 1587 with the marks of a small capital $\mathrm{H}$ and the initials I. C. Another interesting piece of Hull plate is at Trinity House. It is a nut, mounted in silver by Robert Robinson, whose initials are found with the three ducal crowns for Hull. The later, and characteristic Communion Cup, made by Edward Mangey of Kingston-on-Hull at Hornsea (fig. 9) has been already alluded to. Its square-shaped bowl, and the peculiar form of ornamentation, will be noticed by those who have studied the subject.

Among the illustrations will be found that of the curious Leeds marked cup at Almondbury near Huddersfield (fig. 10). Only five pieces of Leeds plate are known, and this coupled with the peculiar look of the cup seems to justify attention being drawn to it on this occasion.

The (fig. 11) Sutton-on-Derwent cup of 1610, represents a common type of York-made vessels with a band of dots round the bowl and cover. This type of York cup is more like the normal London-made cup of the period, than any found elsewhere of provincial origin.

The London-made (fig. 12) Guisbrough tazza of 1604 is interesting, as it has a cover surmounted by a spiral termination. I know of no other tazza of this period with a cover. The churchwardens of Guisbrough had it copied at York in 1640, but the second tazza made by Robert Harrington of that city, although exactly matching it in shape and size, with cover, etc., is perfectly plain. This shows the difference between the work of the London goldsmith and that of his York fellow craftsman, who was unable to punch the elaborate reticulated pattern on the vessel. York goldsmiths' work was good, comely, and substantial, but not elaborate.

The Harthill (fig. 13) silver-gilt altar candlesticks (London, 1675) are the only examples of old silver altar candlesticks in Yorkshire, besides the two sets at York Minster. They tell a mournful tale, which is too often 
To face page 32

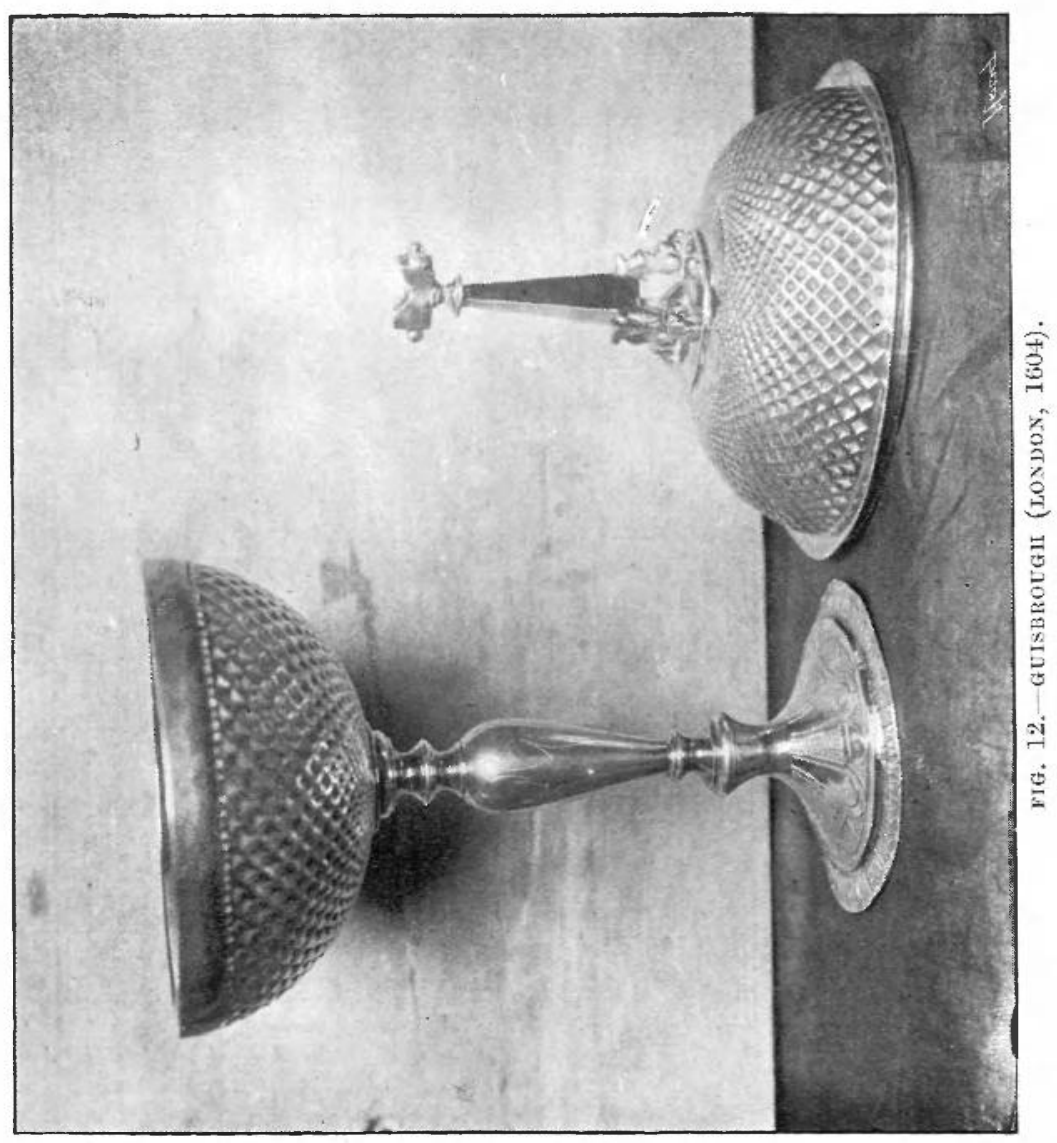


To face page $i 2$.

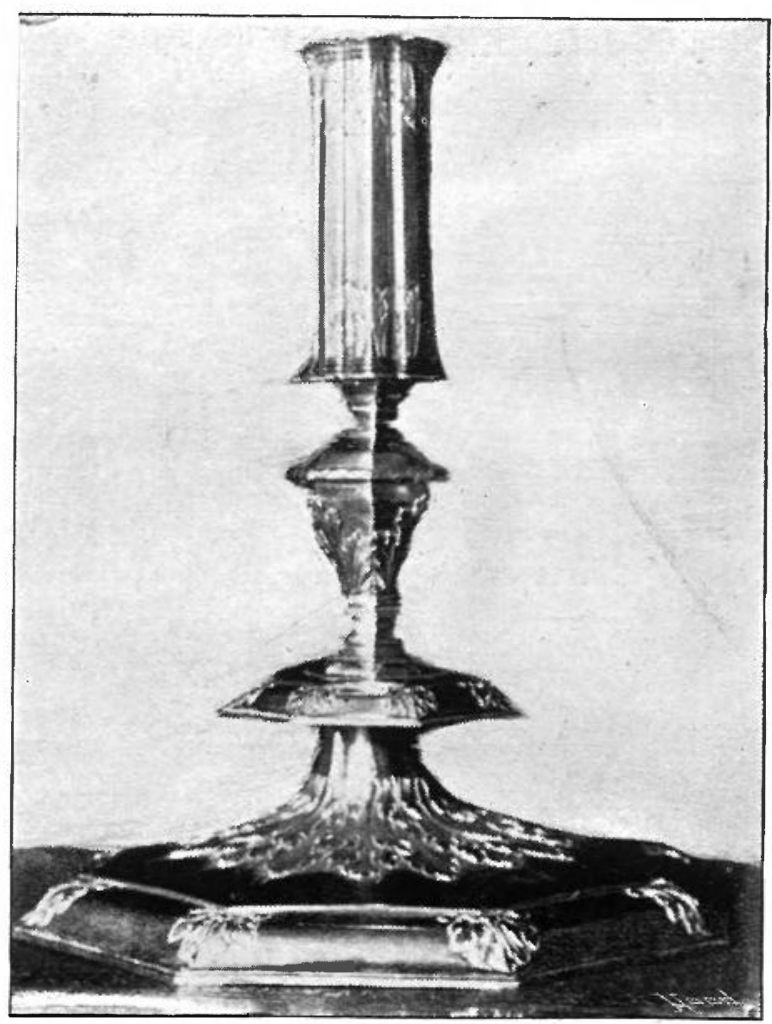

FIG. 13. - HARTHILL ALTAR CANDLEśtick (LOXDON, 1675). 
repeated up and down the country. A late incumbent of the parish (now deceased) thought his plate looked unecclesiastical, so he exchanged away, for some modern rubbish, a magnificent set of plate of which these candlesticks formed part. Each piece bore, as the candlesticks do, an inscription stating that it was the gift of "Peregrine, second Duke of Leeds," to Harthill Church.

Had time sufficed I might have drawn attention to other curious and unusual pieces of Yorkshire goldsmiths work, such for instance as some Arval flagons-Flagons that is, for use at the old Arral or Funeral feasts. I will, however, conclude with mentioning one object which is, I believe, unique. An East Riding Church possesses a gold parochial wedding ring intended for general use. It bears inside the poesy or motto: rule din obep. 